\title{
Moisture sorption characteristics of Rasomalai at different temperatures
}

\author{
Khojare Ajit
}

Received: 21 November 2020 / Accepted: 15 April 2021 / Published online: 07 September 2021

(c) Indian Dairy Association (India) 2021

\begin{abstract}
The sorption characteristics of rasomalai were measured at the temperatures of $20^{\circ} \mathrm{C}, 30^{\circ} \mathrm{C}$, and $40^{\circ} \mathrm{C}$ and found to be in the water activity range of $0.11-0.97$. The isotherm exhibit sigmoid shape and correspond to type II. In rasomalai, at all water activities values of equilibrium moisture content decreased with an increase in storage temperature. However, a clear cut inversion was observed intermittently at $30^{\circ} \mathrm{C}$ and $40^{\circ} \mathrm{C}$. The BET and GAB equation fitted hold good as indicated by the statistical values $\mathrm{R}^{2}, P, \% \mathrm{RMS} \&$ chi square. The BET monolayer value in rasomalai decreased from $5.11 \mathrm{~g}$ of water $/ 100 \mathrm{~g}$ of solids at $20^{\circ} \mathrm{C}$ to $3.80 \mathrm{~g}$ of water $/ 100 \mathrm{~g}$ of solids at $40^{\circ} \mathrm{C}$. The $\mathrm{GAB}$ monolayer value for rasomalai decreased from $5.04 \mathrm{~g}$ of water/ $100 \mathrm{~g}$ of solids at $20^{\circ} \mathrm{C}$ to $3.86 \mathrm{~g}$ of water $/ 100 \mathrm{~g}$ of solids at $40^{\circ} \mathrm{C}$. The Caurie equation was used to determine properties of sorbed water viz., density of sorbed water, number of adsorbed monolayers, bound or non freezabe water and surface area of sorption in rasomalai. The net isosteric heat of sorption in rasomalai ranged from $58.24 \mathrm{~kJ} / \mathrm{mol}$ at $\quad 6.63 \%$ moisture content to $0.44 \mathrm{~kJ} / \mathrm{mol}$ at $32.75 \%$ moisture content.
\end{abstract}

Ajit Khojare $(\square)$

Department of Dairy Science \& Technology, Vivekanand College, Samarth Nagar, Aurangabad, 431 001, M.S., INDIA

Email:khojare@yahoo.com
Keywords: Models, Rasomalai, Sorption Isotherm, Sorbed water, Water Activity,

\section{Introduction}

The history of Indian milk products is perhaps as old as Indian civilization itself. Traditional milk products represent the most prolific segment of our Indian Dairy Industry. Rasomalai is very popular traditional Indian dairy products originated in eastern parts of India. It is flattened chhana patties floating in thickened sweet milk. It is a very delicate, chewy/spongy sweet (Aneja et al. 2002).

India is world's largest milk producer with annual milk production of around 187.70 million tonnes in the year 2018-2019. Surplus milk (about $50 \%$ ) converted into a variety of traditional products as a means of preservation (Rajorhia, 2020). Despite the immensity of volume of milk handled, preparation and marketing of these products are mostly confined to the unorganized sector due to lack of process up-gradation and standardization. Rasomalai is still produced manually in small sector with variable qualities depends upon the skills of halwais (Sharma et al. 2014). For the process upgradation, packaging and storage, data of equilibrium moisture content are needed which may be expressed in moisture sorption isotherms.

The moisture sorption isotherms describe the equilibrium relationship between water activity and moisture content of food, at constant temperature and pressure, wherein water molecules combine reversibly with food solids. The knowledge of sorption behaviour and water activity is useful to predict chemical, physical and microbiological stability of foods as a function of moisture content of the product (Rao et al. 2006). Moisture sorption behaviour of milk products and their constituents are important for understanding the problems of caking, swelling, browning reactions, mold growth and development of rancidity (Bandopadhyay et al. 1987).

The relation between the water activity and the moisture content in food can be expressed mathematically. Diverse linear, non linear and regression models have been developed which explains each one of the three zones of sorption isotherm (Ricardo et al, 2011). 
The BET and GAB equations are widely used for modelling of sorption isotherms of foods (Rahman \& Rashid, 2006). Different properties of sorbed water could be obtained from the model proposed by Caurie (1981).

The isosteric heat of sorption $\left(\mathrm{Q}_{\mathrm{st}}\right)$ is the measure of binding energy of water molecules sorbed by the solutes of the product and it helps in estimating the energy needed to remove the portion of water from the product ( Sormolai and Langrish, 2015). This thermodynamic property is quite a valuable tool in understanding a mechanism of sorption behaviour in foods (Rizvi,2005).

The moisture sorption characteristics data is extremely valuable in describing the intrinsic processing and storage induced changes in food quality. Therefore the study was carried out to establish the moisture sorption characteristics and properties of sorbed water of Rasomalai in the temperature range of 20 to $40^{\circ} \mathrm{C}$.

\section{Material and Methods}

\section{Preparation of Rasomalai}

The Rasomalai was prepared as per the method reported (Aneja et al.2002). Fresh cow milk obtained from the local market and standardized to $3.5 \%$ fat and $8.5 \%$ SNF was used for preparation of Rasomalai. Initially, milk was heated to $90^{\circ} \mathrm{C}$ and cooled to $70^{\circ} \mathrm{C}$. The hot milk was coagulated by using $1 \%$ solution of food-grade citric acid as an acidulant that was previously heated to the milk temperature, adding and stirring gently without breaking the coagulum, till the clear whey appears. The whey was removed by draining through the cleaned and sanitized muslin cloth by hanging the coagulated mass till the dripping of the whey ceased. The obtained channa is kneaded in to smooth dough. The dough is portioned and rolled into balls of size 15 mm having smooth texture without cracks. The balls were then flattened like patties. These flattened patties were cooked in clear sugar syrup ( $40^{\circ}$ Brix) for 15 minutes. During cooking small amount of water was added to makeup water loss due to evaporation and to maintain sugar syrup concentration. After cooking the channa patties were transferred to a container with water at $30-35^{\circ} \mathrm{C}$ for texture stabilization and colour improvement for 10 minutes. The texturized channa patties were then transferred to 50-60\% sugar syrup for first stage dipping for two hours followed by second dipping in 40-50\% sugar syrup for two hours. The sweet swollen channa patties were subsequently stored in sweetened milk (5 to 6 percent sugar $(\mathrm{w} / \mathrm{v}))$ condensed to one fourth of its volume. The flattened patties of rasomalai soaked in sweetened milk were removed and used for moisture sorption experimentation.

\section{Compositional analysis}

The proximate compositional analysis of rasomalai was done as per BIS: SP: 18 (Part XI)-1981 and AOAC (2005). The approximate composition of the products obtained as moisture $54.34 \%$, Protein $8.24 \%$, Fat $7.27 \%$, Ash $2.2 \%$ and total sugars $27.95 \%$.

\section{Determination of sorption isotherm:}

To study the moisture sorption phenomenon in rasomalai the static gravimetric method was used as recommend by Sablani et al (2001). The sorption devices consisted of airtight sealed wide mouth glass bottles in which sample was placed in small container and exposed to the humid atmosphere created in the bottle. The array of sample bottles in triplicate were placed in the temperature controlled chambers at $20^{\circ} \mathrm{C}, 30^{\circ} \mathrm{C}$ and $40^{\circ} \mathrm{C}$. To create humid atmosphere, reagent grade salt solutions (saturated slush) were prepared for the water activity values of $0.11-0.97$ (Greenspan, 1977). Approximately $2 \mathrm{~g}$ of rasomalai was weighed in each sample container. To prevent microbial growth approximately $0.005 \mathrm{~g}$ of potassium sorbate was added to each sample. The weight of the samples were taken at the regular intervals after every third day until there was no change in weight $( \pm 0.0001 \mathrm{~g})$ for three consecutive readings. The rasomalai samples took three weeks to reach equilibrium. The total time of weighing and replacing the sample did not exceed 30s for all trials. An average of triplicate measurement was used to develop the moisture sorption isotherms.

\section{Isotherm models and calculations}

BET (Brunauer- Emmet-Teller) and GAB (Guggenheim-AndersonDeBoer)equations are widely reported for modelling of sorption isotherms of foods (Rahman \&Rashid, 2006) and therefore both the models were selected to ascertain their predictability for moisture sorption data of rasomalai and to estimate critical moisture sorption parameters. The BET monolayer moisture content is sometimes considered the most stable moisture content in food. However, BET relationship is only valid up to $\mathrm{a}_{\mathrm{w}}=$ 0.55.BET model is given as:

$$
\frac{a_{\mathrm{w}}}{\left(1-a_{\mathrm{w}}\right) W}=\frac{1}{W_{0} \mathrm{C}}+\frac{\mathrm{C}-1}{W_{0} \mathrm{C}} \times a_{\mathrm{w}}
$$

Where, ' $W$ ' is the moisture content $(\mathrm{db}), \mathrm{a}_{\mathrm{w}}$ is the water activity, $W_{0}$ is the monolayer moisture content, $\mathrm{C}$ is a surface heat constant. The slope obtained from the plot of $1 /\left(1-a_{w}\right)$ versus allows the determination of BET parameters. The GAB model is most popular model reported to fit for entire range of water activity by second degree polynomial. It is given as:

$$
\frac{W}{W_{0}}=\frac{G \mathrm{k} a_{\mathrm{w}}}{\left(1-\mathrm{k} a_{\mathrm{w}}\right)\left(1-\mathrm{k} a_{\mathrm{w}}+G \mathrm{k} a_{\mathrm{w}}\right)}
$$

Where, $\mathrm{k}$ is a multilayer factorand $G$ is Guggenheimconstant in $\mathrm{GAB}$ equation. The GAB parameters can be determined by linear multiple regression after parabolic transformation of the equation 2 . 
Caurie equation(Caurie, 1981) is an improvement in BET equation and is most useful to determine properties of sorbed water in foods.

$$
\ln \frac{1}{W}=-\ln \frac{1}{C W_{0}}+\frac{2 C}{W_{0}} \ln \frac{\left(1-a_{\mathrm{w}}\right)}{a_{\mathrm{w}}}
$$

Where, in equation 3 isdensity of sorbed water in foods.Caurie's plot of $\left(1-\mathrm{a} / \mathrm{a}_{\mathrm{w}}\right)$ versus $\ln (1 / w)$ over the $\mathrm{a}_{\mathrm{w}}$ range was used to obtain Caurie's slope $(S)$. The number of adsorbed monolayers was obtained by the formulae:

$$
S=\frac{2}{N}
$$

Percent bound water or non freezable water is the product of monolayer value $\left(w_{\mathrm{o}}\right)$ in the Caurie equation and number of adsorbed monolayers $(N)$. The surface area of adsorption $(A)$ was determined by the formula:

$$
A=\frac{54.54}{S}
$$

\section{Net isosteric heat of sorption}

Net isosteric heat of sorption can be calculated using ClausiusClapeyron equation, relating the water activities and temperatures at a fixed moisture content (Bell and Labuza, 2000).

$$
q_{n}^{s t}=\mathrm{R}\left[\frac{T_{1} T_{2}}{T_{2}-T_{1}}\right]\left[\ln \frac{a_{\mathrm{w} 2}}{a_{\mathrm{w} 1}}\right]
$$

Where, is the isosteric sorption heat $(\mathrm{kJ} / \mathrm{mol}), \mathrm{R}$ is the gas constant $(0.00831434 \mathrm{~kJ} / \mathrm{mol} \mathrm{K})$ and $T_{1}, T_{2}$ are the absolute temperatures $(\mathrm{K})$. This procedure assumes that heat of sorption is independent of temperature change. The plot of net isosteric heat of sorption versus moisture content gives the change in energy values to eject the molecules of water from food products.

\section{Statistical analysis}

In order to compare the precision of fit of the sorption data in selected mathematical models, statistical tools such as coefficient of determination $\left(\mathrm{R}^{2}\right)$, mean relative percent deviation modulus $(P)$, percent root mean square error percent (\%RMS) and chi square test were used (Best \& Kahn, 1998).

\section{Results and Discussion}

The sorption isotherm of rasomalai was measured at the temperatures of $20^{\circ} \mathrm{C}, 30^{\circ} \mathrm{C}$, and $40^{\circ} \mathrm{C}$ and in the water activity range of $0.11-0.97$. The isotherms plotted by joining the experimental values of the equilibrium moisture content against different water activities at the temperature maintained are presented in Fig. 1.

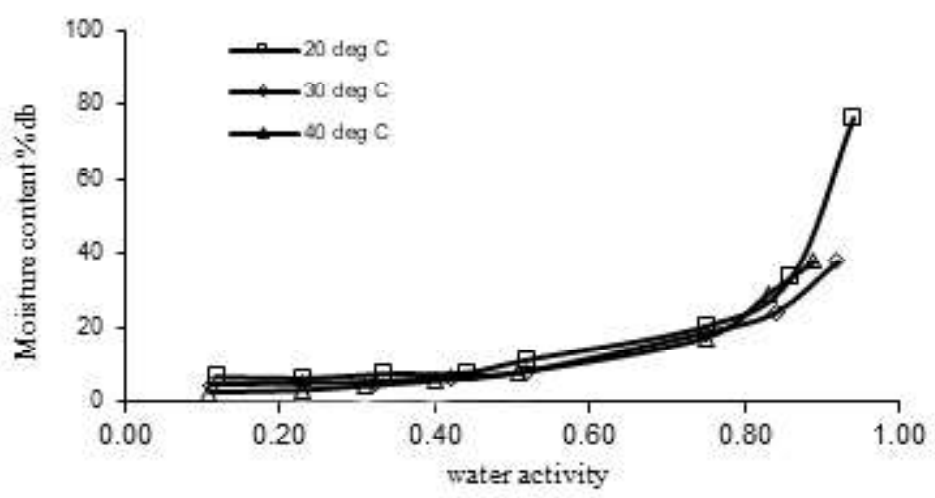

Fig 1 Moisture sorption isotherms of Rasomalai at different temperatures

For rasomalai, part of the isotherm data was obtained by adsorption, where the water activity of the salt slurries was below initial $\mathrm{a}_{\mathrm{w}}$ of the material and rest desorption where the water activity of salt slurries was above initial $\mathrm{a}_{\mathrm{w}}$ of the material. The isotherm thus obtained for rasomalai exhibit sigmoid shape and correspond to type II as per the classification of Brunauer (Ricardo et al.2011). The sigmoid shape of isotherm was also reported for other Indian dairy and products viz., Khoa Peda (Pagire et al. 2020), Kalakand (Deshmukh et al. 2018), Shrikhand (Khojare,2018), Bottle Guard Burfi (Quadri et al. 2016), Cham-Cham (Puri\&Khamuri,2015), Sandesh (Khojare,2014; Khojare \& Hembade, 2016; Sahu \& Das, 2010), Dietetic Rabri (Ghayal et al. 2013), Dietetic Chhana Kheer (Gautam et al. 2018), Peda (Biradar et al. 1985; Kumar et al. 2012), ready to use Basundi mix (Sharma et al. 2009), Curd powder (Varghese et al. 2008), Chhana podo (Rao et al. 2006.), Milk Burfi (Ramakrishna et al. 2005), Kheer (Jayendra Kumar et al. 2005), Dudh churpi (Hossain et al. 2002), Khoa (Sawhney \& Cheryan, 1988) and Chhana powder \& Casein (Bandyopadhyay et al. 1987).

From Fig. 1 is observed that the equilibrium moisture content in rasomalai isotherm rose gradually at lower water activities 0.12 -0.44 at $20^{\circ} \mathrm{C}, 0.11-0.52$ at $30^{\circ} \mathrm{C}$ and $0.11-0.51$ at $40^{\circ} \mathrm{C}$ followed by an accelerated rise at higher water activities at all the three temperatures. Also at all the temperatures, as the water activity increased EMC also increased. The EMC at $20^{\circ} \mathrm{C}, 30^{\circ} \mathrm{C}$, and $40^{\circ} \mathrm{C}$, increased from $7.18 \%, 4.50 \%$ and $2.69 \%$ at around $0.12,0.11$ and $0.11 \mathrm{a}_{\mathrm{w}}$ to $76.26 \%, 37.90 \%$ and $37.90 \%$ at $0.94,0.92$ and $0.89 \mathrm{a}_{\mathrm{w}}$ respectively. Rasomalai isotherms showed three regions of typical isotherm reported for milk proteins (Kinsella and Fox,1987).

\section{Effect of temperature on sorption isotherm of rasomalai}

In rasomalai, at constant water activity level, values of equilibrium moisture content decreased as an increase in temperature viz., the EMC at around $\mathrm{a}_{\mathrm{w}}$ of 0.50 is 11.76 at $20^{\circ} \mathrm{C}$ compared to 8.22 and 8.01 at $30^{\circ} \mathrm{C}$ and $40^{\circ} \mathrm{C}$ respectively. The negative temperature effect on the EMC has often been observed 
in foods with high protein content (Okos et al.1992). It has also been reported that the water activity shift by temperature is mainly due to changes in water binding, dissociation of water and or increase of solute solubility in water. For constant water content, the increase in water activity with temperature indicates that the sorption in rasomalai is an exothermic process as activity potential increased to retain constant moisture content $(\Delta \mathrm{G}=$ $\Delta \mathrm{H}-\mathrm{T} \Delta \mathrm{S})$. However, it is observed from Fig. 1 that, in the isotherm plot of rasomalai at $30^{\circ} \mathrm{C}$ and $40^{\circ} \mathrm{C}$ as the water activity and temperature increased the swinging (crossing over) of isotherms took place intermittently. This inversion is due to the fact that at lower temperature water activity values sorption takes place mostly by biopolymers but as the water activity and temperature increased beyond the intermediate region, moisture begins to sorbed primarily by the sugars and other low molecular constituents leading to swinging of isotherms (Saravacos and Stinchfield,1965). Rasomalai contain relatively high level of sugars $(27.95 \%)$ and it is reported that dissolution of sugars at high temperature offset the opposite effect of temperatures on high molecular weight compounds (Aviara,2020). Similar phenomenon was observed by Sharma et al. (2009) in ready to use basundi mix.

\section{Fitting of sorption isotherm models to rasomalai}

For rasomalai $\mathrm{BET}$ and $\mathrm{GAB}$ models were used to predict the experimental moisture sorption data and to understand the sorption behaviour of the product. It could be observed from Table 1 that for rasomalai the BET equation hold good within water activity range of 0.11 to 0.52 .
Though the BET model is valid over the limited range of water activity, the BET monolayer represents tightly bound water and could be suggested as optimum water content for the stability of rasomalai. The chemical reactions are therefore expected to be slow in monolayer region. From Table 1 it could be observed that the BET monolayer value in rasomalai decreased from $5.11 \mathrm{~g}$ of water $/ 100 \mathrm{~g}$ of solids at $20^{\circ} \mathrm{C}$ to $3.89 \mathrm{~g}$ of water $/ 100 \mathrm{~g}$ of solids at $30^{\circ} \mathrm{C}$ and it was further decreased to $3.80 \mathrm{~g}$ of water $/ 100 \mathrm{~g}$ of solids at $40^{\circ} \mathrm{C}$. The negative temperature effect on EMC has often been observed in foods with high protein content. (Jayendra et al. 2005; Okos et al.1992; Delgado and Sun, 2002a,b).

$\mathrm{GAB}$ equation on the other hand is fitted to the moisture sorption data of rasomalai in the water activity range of 0.11-0.94. The equation holds good as indicated by the statistical values viz., $\mathrm{R}^{2}, P$ and \%RMS shown in Table 2 .

Since $\mathrm{GAB}$ equation is useful to predict the moisture data over an entire range of water activity the graph was plotted using the GAB predicted values for rasomalai and shown in Fig. 2. The GAB monolayer value calculated for rasomalai (Table, 2) was decreases from $5.04 \mathrm{~g}$ of water $/ 100 \mathrm{~g}$ of solids at $20^{\circ} \mathrm{C}$ to $4.00 \mathrm{~g}$ of water $/ 100 \mathrm{~g}$ of solids at $30^{\circ} \mathrm{C}$, it was further decreased to $3.86 \mathrm{~g}$ of water $/ 100 \mathrm{~g}$ of solids at $40^{\circ} \mathrm{C}$. For both the equations the statistical agreement between the experimental and predicted values are quite satisfactory and well within the limits of experimental error. Furthermore, it was observed from Table 1 and 2 that, there is no significant difference as inferred from unpaired $t$ test $(\mathrm{P}=0.95$ and $\mathrm{df}=4$ ) in the monolayer moisture contents calculated from the BET and GAB equation.

Table 1 Estimated parameters of BET isotherm equation fitted to sorption data of Rasomalaiat different temperatures

\begin{tabular}{lllllll}
\hline Temp ${ }^{\circ} \mathrm{C}$ & $\begin{array}{l}W_{0} \\
\text { g water/100g } \\
\text { Solids }\end{array}$ & $\mathrm{C}$ & $\mathrm{R}^{2}$ & $\mathrm{P}$ & \%RMS & $\chi^{2}$ \\
\hline 20 & 5.11 & -124.30 & 0.95 & 9.15 & 9.23 & 1.33 \\
30 & 3.89 & 273.52 & 0.99 & 3.11 & 3.08 & 3.51 \\
40 & 3.80 & 10.80 & 0.92 & 9.80 & 9.39 & 0.61 \\
\hline
\end{tabular}

Table 2 Estimated parameters of GAB equation fitted to sorption data of Rasomalai at different temperatures

\begin{tabular}{llllllll}
\hline Temp ${ }^{\circ} \mathrm{C}$ & $W_{0}$ & $\mathrm{~K}$ & $\mathrm{C}$ & $\mathrm{R} 2$ & $\mathrm{P}$ & \%RMS & $\chi^{2}$ \\
& g water/100g solids & & & & & & 0.39 \\
\hline 20 & 5.04 & 0.09 & -57.86 & 0.95 & 5.57 & 5.11 & 2.31 \\
30 & 4.00 & 0.99 & 65.31 & 0.94 & 7.75 & 8.88 & 2.37 \\
40 & 3.86 & 1.03 & 9.39 & 0.92 & 9.54 & 8.31 & \\
\hline
\end{tabular}

Table 3 Properties of sorbed water in Rasomalai at different temperatures

\begin{tabular}{llllc}
\hline Temp.${ }^{\circ} \mathrm{C}$ & $\begin{array}{l}\text { Density of } \\
\text { sorbed } \\
\text { water }(C)(\mathrm{g} / \mathrm{cc})\end{array}$ & $\begin{array}{l}\text { No. of } \\
\text { adsorbed } \\
\text { monolayers }(N)\end{array}$ & $\begin{array}{l}\text { Bound or } \\
\text { nonfreezable } \\
\text { water }\left(w_{\mathrm{o}} \mathrm{x} N\right)(\%)\end{array}$ & $\begin{array}{c}\text { Surface } \\
\text { areaof } \\
\text { sorption }(A) \mathrm{m}^{2} / \mathrm{g}\end{array}$ \\
\hline 20 & 1.42 & 3.80 & 20.54 & 103.85 \\
30 & 1.97 & 3.11 & 19.15 & 85.03 \\
40 & 2.19 & 2.62 & 15.09 & 71.63 \\
\hline
\end{tabular}




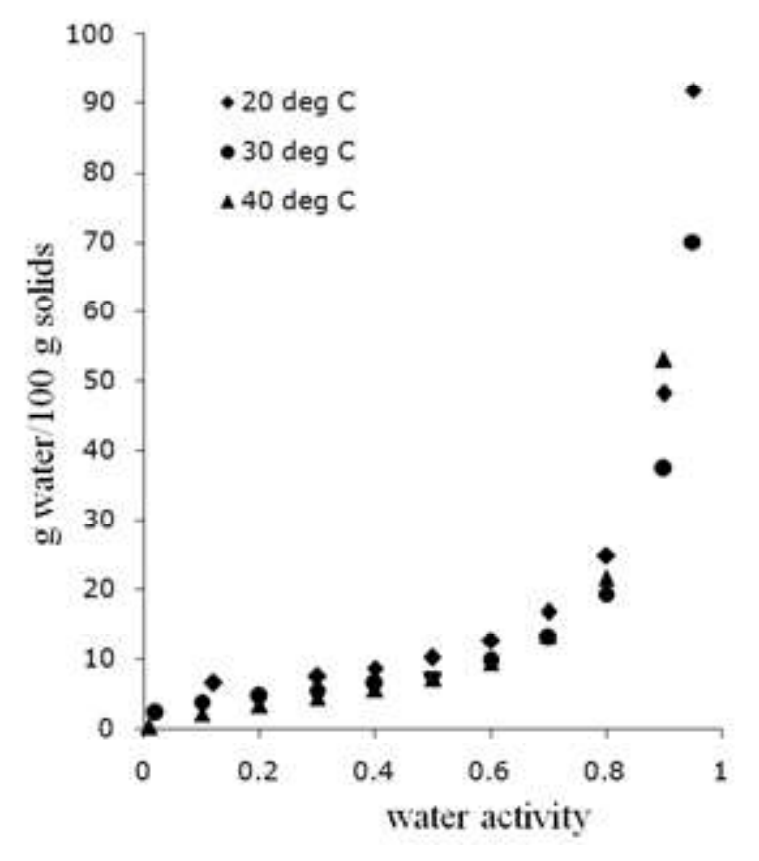

Fig. 2 Predicted values of EMC of Rasomalai at different temperatures using GAB model

\section{Properties of sorbed water in rasomalai}

The Caurie equation (Eqn. 3) is highly been recommended to determine properties of sorbed water in food products (Rao et al, 2006). This model has been used to characterize sorption behaviour of dudh churpi by fitting an equation to an entire range of water activity (Hossain et al. 2002). Therefore, Caurie equation was used to determine properties of sorbed water in rasomalai viz., density of sorbed water, number of adsorbed monolayers, bound or non freezabe water and surface area of sorption in rasomalai. The properties of sorbed water in rasomalai were determined at $20^{\circ} \mathrm{C}, 30^{\circ} \mathrm{C}$ and $40^{\circ} \mathrm{C}$ and presented in the Table 3.

It is observed from the table 3 that in rasomalai density of sorbed water increased from $1.42 \mathrm{~g} / \mathrm{cc}$ at $20^{\circ} \mathrm{C}$ to $1.97 \mathrm{~g} / \mathrm{cc}$ at $30^{\circ} \mathrm{C}$ and it was further increased to $2.19 \mathrm{~g} / \mathrm{cc}$ when temperature increased to $40^{\circ} \mathrm{C}$. Similar observations also reported by Sharma et al (2009) in ready to use basundi mix. Bound or non-freezable water in rasomalai decreased from $20.54 \%$ at $20^{\circ} \mathrm{C}$ to $19.15 \%$ at $30^{\circ} \mathrm{C}$. It was further decreased to $15.09 \%$ when temperature rose to $40^{\circ} \mathrm{C}$. The surface area of sorption decreased from $103.85 \mathrm{~m}^{2} / \mathrm{g}$ at $20^{\circ} \mathrm{C}$ to $85.03 \mathrm{~m}^{2} / \mathrm{g}$ at $30^{\circ} \mathrm{C}$, it was further decreased to $71.63 \mathrm{~m}^{2} / \mathrm{g}$ at $30^{\circ} \mathrm{C}$. This indicates that the total number of binding sites decreased through protein-protein, protein - carbohydrate and protein lipid interaction (Jayendra et al. 2005). This also reflects a reduction in exposure of charged polar groups and carboxyl function of peptide bonds that binds water.

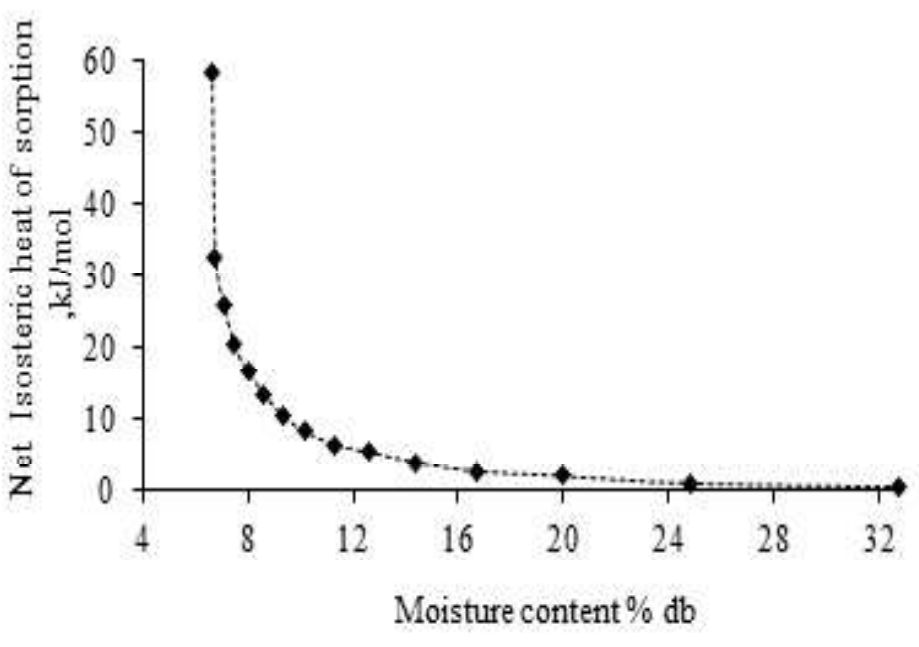

Fig. 3Net isosteric heat of sorption of Rasomalai at different moisture content

\section{Net heat of sorption of rasomalai}

The net isosteric heat of sorption varies with the amount of water absorbed by the substrate. The Clausius-Clapeyron equation (Eqn 6) was used to calculate net isosteric heat of sorption in rasomalai as a function of moisture content by considering $20^{\circ} \mathrm{C}$ to $40^{\circ} \mathrm{C}$ as $\mathrm{T}_{1}$ and $\mathrm{T}_{2}$. The relationship between net isosteric heat of sorption and moisture content is plotted (Fig.3).

The net heat of adsorption decreased with increased in moisture content, initially rapidly up to $19.97 \mathrm{~g}$ of water $/ 100 \mathrm{~g}$ of solids and latter approached a constant value as observed in many other food systems (Khojare \& Hembade, 2016, Rao et al. 2006, Sawhney et al, 1991). The decrease in the net isosteric heat of sorption in rasomalai with increase in amount of water sorbed is due to the fact that initially, sorption occurs on the most active sites, giving rise to higher energy of interaction between the sorbate and the sorption sites. As these active sites become occupied, sorption subsequently occurred on the less active site in rasomalai giving lower heat of sorption. Therefore, the water binding in rasomalai is weak till the moisture content reaches to $19.97 \%$. It was observed that, quite a substantial amount of energy must be supplied to desorb the last traces of water from rasomalai. The net isosteric heat of sorption in rasomalai ranged from $58.24 \mathrm{~kJ} / \mathrm{mol}$ at $6.63 \%$ moisture content to $0.44 \mathrm{~kJ} / \mathrm{mol}$ at $32.75 \%$ moisture content. 


\section{Conclusions}

The moisture sorption isotherm of rasomalai was measured at three temperatures of $20^{\circ} \mathrm{C}, 30^{\circ} \mathrm{C}$, and $40^{\circ} \mathrm{C}$ and in the water activity range of $0.11-0.97$. The isotherm exhibits sigmoid shape and correspond to type II. A clear cut inversion was observed in rasomalai isotherms at $30^{\circ} \mathrm{C}$ and $40^{\circ} \mathrm{C}$ could be attributed to solubility of sugar at high temperatures. The BET and GAB equation fitted to sorption data of rasomalai hold good as indicated by the statistical tools. Though the BET and GAB monolayer values reported are useful to understand sorption behaviour of water in rasomalai, GAB equation could be more useful as it has the capability to fit to an entire range of water activity than BET. The properties of sorbed water viz., density of sorbed water, number of adsorbed monolayers, bound or non freezabe water and surface area of sorption were calculated by Caurie equation. The heat of adsorption decreased with increased in moisture content, initially rapidly up to $19.97 \mathrm{~g}$ of water $/ 100 \mathrm{~g}$ of solids and latter approached a constant value as observed in many other food systems.

\section{References}

Aneja RP, Mathur BN, Chandan RC, Banarjee AK (2002) Technology of Indian Milk Products. In P.R. Gupta (Ed.), New Delhi, India

AOAC (2005) Official Methods of Analysis of AOAC International. $\left(18^{\text {th }} \mathrm{Edn}\right), \mathrm{AOAC} \quad$ International suite 500, 481 North Frederic Avenue Gaithersburg, Maryland,USA

Aviara NA (2020) Moisture Sorption Isotherms and Isotherm Model Performance Evaluation

for Food and Agricultural Products. In Intech Open DOI: $\underline{h t t p: / / d x . d o i . o r g / ~}$ 10.5772/intechopen.87996

Bandyopadhyay P, Das H, Sharma GP (1987) Moisture adsorption characteristics of casein, lactose, skim milk and chhana powder. J Food Sci Technol 24:6-11

Bell LN, Labuza TP (2000) Moisture sorption: Practical aspects of isotherm measurement and use, $\left(2^{\text {nd }} E d n\right)$ AACC, St. Paul, MN

Best JW, Kahn JV (1998) Research in Education, (8 ${ }^{\text {th }}$ Edn) Allyn \& Bacon, Needham Heights MA 02194

Biradar US, Dev DK, Ingale UM (1985) Shelf life extension of pedha by Packaging. J. Food Sci. 50: 51-55.

BIS (1981) Handbook of Food Analysis ISI-Part XI Dairy Products. Bureau of Indian Standards, New Delhi

Caurie M (1981) Derivation of full range moisture sorption isotherms. In: Rockland LB,

Stewert GF (ed) Water activity: Influence on food quality. Academic Press New York, pp 63-87

Delgado AE, Sun DW (2002a) Desorption isotherms and glass transition temperature for chicken meat. J Food Eng 51: 1-8

Delgado AE, Sun DW (2002b) Desorption isotherms of cooked and cured beef and pork.J Food Eng. 51: 163-170

Deshmukh G, Bhadania AG, Birwal P, DatirR, Patel S (2018) Moisture sorption characteristics of Kalakand- a traditional Indian dairy product. Indian J Dairy Sci 71: 28-34

Gautam AK, Tanweer A, Bhardwaj A, Jha A (2018) Thermodynamic analysis of experimental sorption isotherms of dietetic chhana kheer. Madridge J Food Technol 3: 126-131
Ghayal G, Jha A, Sahu JK, Kumar A, Gautam A (2013) Moisture sorption isotherms of dietetic Rabri at different storage temperatures. Int $\mathrm{J}$ Dairy Technol 66: 587-594

Greenspan L (1977) Humidity fixed points of binary saturated aqueous solutions. Journal of Research of National Bureau of Standards -A Physics and Chemistry 81A: 89-96

Hossain SA, Pal PK, Sarkar PK, Patil GR (2002) Moisture sorption characteristics of dudh churpi, a traditional milk products in India. Nahrung 46: 136-140

Jayendra KA, Singh RRB, Patil GR, Patel AA (2005) Effect of temperature on moisture desorption isotherm of kheer. LibensmWiss Technol 38: $303-310$

Khojare AS (2018) Moisture sorption characteristics of Shrikhand at $20^{\circ} \mathrm{C}$ and $30^{\circ} \mathrm{C}$. Indian J Dairy Sci 71: 381-388

Khojare AS (2014) Moisture Sorption Hysteresis in Sandesh at $20^{\circ} \mathrm{C}$. Asian J Dairy Food Res 33: 179-182

Khojare AS, Hembade AS (2016) Moisture Adsorption Characteristics of Sandesh Powder. Indian J Dairy Sci 69: 259-266

Kinsella JE, Fox PF (1987) Water sorption by proteins: milk and whey proteins. Bulletin of International Dairy Federation No. 209: 1240

Kumar A, Jha A, Jain P, Sahu JK, Arora S (2012) Moisture sorption characteristics of lal peda at different storage temperatures. Food Res Int 49: 373-378

Okos MR, Narsimhan G, Singh RK, Weitnauer AC (1992) Food dehydration. In: Heldman

DR, Lund DB (ed) Handbook of Food Engineering, Marcel Dekker, New York 437-562

Pagire SG, WarrierAS, Sawhney IK (2020) Moisture sorption Characteristics of heat desiccated milk sweet 'Khoa peda' prepared from buffalo milk. Indian J Dairy Sci 73: 321-239

Puri R, Khamrui K (2016) Effect of temperature on sorption isotherms and thermodynamics

of intermediate moisture category Indian milk product cham-cham. J Food Process Pres 40: 999-1009

Quadri SA, Khojare AS, Ingle MP (2016) Sorption Characteristics of bottle gourd burfi. Acta Scientifica Int J Food Nutr 1: 42-53

Rajorhia GS, (2020) Consumer Centric New Product opportunities, Indian Dairyman, New Delhi, 72:10-11

Rahman SR, Rashid HA (2006) Dynamic Isopiestic Method (DIM): Measuring Moisture Sorption Isotherm of Freeze-Dried Garlic Powder and Other Potential Uses of DIM, Int J Food Prop 9: 421-437. DOI: 10.1080/10942910600596134

Ramakrishna C, Ponnachanna CS, Reddy S (2005) Moisture sorption characteristics of milk

burfi, traditional Indian sweet, using sugar substitutes. Eur Food Res Technol 220: 136-141

Rao KJ, Dhas PHA, Emerald FME, Ghosh, BC, BalasubramanyamBV, Kulkarni S (2006) Moisture sorption characteristics of Chhana podo at $5^{\circ} \mathrm{C}$ and $35^{\circ} \mathrm{C}$. J Food Eng 76:453-459

Ricardo D, Andrade P, Roberto LM, Carmen EP (2011) Models for sorption isotherms for foods: uses and limitations, Vitae, Revista De La Facultad De Química Farmacéutica, 18: 325-334

Rizvi SSH (2005) Thermodynamic properties of food in dehydration. In: Rao MA, Rizvi SSH \& Datta AK (ed) Engineering properties of foods, 3rd edn, CRC Press, pp. 239-326

Sablani SS, Rahman M, Labuza, TP (2001) Measurement of Water activity using Isopiestic Method.In: Current Protocols in Food Analytical Chemistry, John Wiley \& Sons, Inc. pp A2.3.1-A 2.3.10

Sahu JK, Das H (2010) Moisture sorption isotherms, properties of sorbed water and heat of sorption of sandesh-an Indian milk product. J Food Process Preserv 34: 152-166 
Saravacos GD, Stinchfield, RM (1965) Effect of temperature and pressure on sorption and water vapour by freeze dried food materials. J Food Sci 30: 779-786

Sawhney IK, Cherian M (1988 Moisture sorption characteristics of heat desiccated whole milk product. LibensmWiss. Technol 21:239-241

Sawhney IK, Patil GR, Kumar B (1991) Effect of temperature on the moisture sorption isotherms of a heat-treated whole milk product, khoa. J Dairy Res 58: 329- 335

Sharma SP, Kapoor CM, Khanna S, Rani M, Bishnao S, Ahlawat SS (2014)

Technological aspects of indigenous chhana based rasmalai, Haryana Vet 53: $124-126$
Sharma P, Singh RRB, Singh AK, Patel AA, Patil GR (2009) Sorption isotherms and thermodynamics of water sorption of ready-to-use Basundi mix. Libensm.Wiss. Technol 42: 441-445

Sormoli M, Langrish T (2015) Moisture sorption isotherms and net isosteric heat of sorption for spray-dried pure orange juice powder, Libensm.Wiss. Technol. 62: 875-882. DOI: 10.1016/ j.lwt.2014.09.064

Varghese SK, Nair SV, Mishra HN (2008) Moisture sorption characteristics of curd (Indian yogurt) powder. Int J Dairy Technol 62: 85-92 